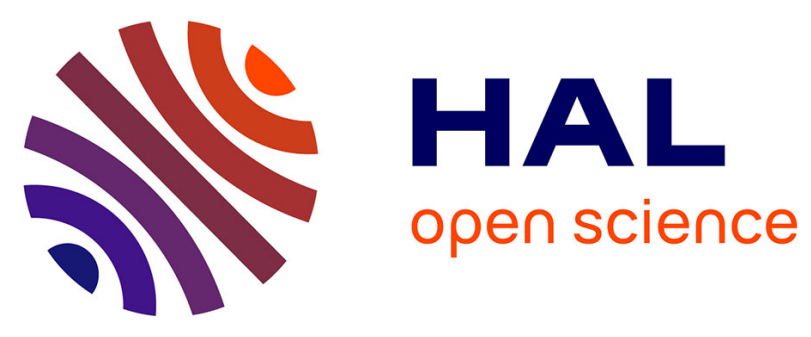

\title{
Rapid climatic change and social transformations
}

\author{
Laurent Lespez, Laurent Carozza, Jean François Berger, Catherine
}

Kuzucuoğlu, Matthieu Ghilardi, Jean-Michel Carozza, Boris Vannière

\section{To cite this version:}

Laurent Lespez, Laurent Carozza, Jean François Berger, Catherine Kuzucuoğlu, Matthieu Ghilardi, et al.. Rapid climatic change and social transformations: Uncertainties, adaptability and resilience. Stéphanie Thiébault; Jean-Paul Moatti. The Mediterranean Region under Climate Change, IRD Edition, 13 p., 2016, 978-2-7099-2219-7. 10.4000/books.irdeditions.22959 . hal-01445619

\section{HAL Id: hal-01445619 https://hal.science/hal-01445619}

Submitted on 9 Nov 2020

HAL is a multi-disciplinary open access archive for the deposit and dissemination of scientific research documents, whether they are published or not. The documents may come from teaching and research institutions in France or abroad, or from public or private research centers.
L'archive ouverte pluridisciplinaire HAL, est destinée au dépôt et à la diffusion de documents scientifiques de niveau recherche, publiés ou non, émanant des établissements d'enseignement et de recherche français ou étrangers, des laboratoires publics ou privés. 


\title{
Rapid climatic change and social transformations Uncertainties, adaptability and resilience
}

\author{
Laurent LESPEZ \\ CNRS, LGP, France \\ Laurent CAROZZA \\ CNRS, GEODE, France \\ Jean-François BERGER \\ CNRS, EVS, France \\ Catherine KuzUCUOGLU \\ CNRS, LGP, France \\ Matthieu GHILARDI \\ CNRS, CEREGE, France \\ Jean-Michel CAROZZA \\ University of La Rochelle, LIENSS, France \\ Boris VANNIERE \\ CNRS, Chrono-Environnement, France
}

\section{Introduction}

Over the past twenty years, palaeoenvironmental research in the Mediterranean has progressed significantly, based mainly on marine, lake, marsh, peat bog and fluvial archives. These records demonstrate a long-standing anthropogenic impact on the Mediterranean ecosystems but also provide evidence of significant climatic instability (e.g. Magny et al. 2013; Vannière et al. 2013) with notable periods 
of Rapid Climatic Change (RCC) observed on the global scale during the Holocene (9.2, 8.2, 6-5, 4.2, 3.2 ka cal. BP; c. 7.2, 6.2, 4-3, 2.2, 1.2 ka BC). In polar records, RCCs that start abruptly within a decade or two at the most and most often concern a period of 150 to 400 years, are often considered among the main environmental factors causing socio-economic and cultural changes, migrations, and even collapses.

According to such climatic determinism, an RCC would be much harder (if not impossible), for a human society to adapt to, thus leading to radical societal transformations (e.g. Weiss et al. 1993; DeMenocal, 2001; Drake, 2012; Weninger et al. 2014) but an increasing number of published studies suggest that the relationship between environmental and cultural changes is more complex and offer a range of non-deterministic explanations (e.g. Butzer, 2012). Starting from this perspective, we have developed a new research project (ArcheoMedPaleomex) in the framework of the MISTRAls initiative to respond to the following questions:

1) What is a natural forcing (timing, nature, origin)?

2) How can a so-called "climate event" produce a social fact: change in material production, resource exploitation, settlement pattern, etc.?

\section{Methods}

We have conducted new archaeological and palaeoenvironmental investigations on an intermediate scale, enabling the cross-comparison of social and environmental data (e.g. Carozza et al. 2012, 2016; Ghilardi et al. 2012, 2016; Glais et al. 2016) to move beyond the observation of co-occurrence and the hypothetical causal link between climate and social change.

Like Flohr et al. (2015) in a recent synthesis about the human consequences of 8.2 and $9.2 \mathrm{ka}$ events in the Near East and in the eastern Mediterranean area, we believe that "more site-specific detailed studies focusing on one ecological base and strategies are needed" and that "this 'bottom-up' approach is now the best way to further the debate. [...] This approach will be time consuming but very worthwhile".

We have developed a multi-scalar approach from the local site (continental natural archive near archaeological sites) to the regional scale. It will then be possible to develop more general conclusions on interactions between nature and society from the local scale to the regional scale - which is also that of the cultural areas - to the entire Mediterranean area. In practical terms, we have developed research in various areas from the south-western to the northeastern part of the Mediterranean basin.

Three main transects are organized in different investigation windows (fig. 1): 
(1) The 'Go-West' transect goes from Eastern Anatolia to the Adriatic, passing through Central Anatolia, Western Anatolia, the western Black Sea coast and Danube delta, Cyprus, Crete, Northern Greece and Corfu Island;

(2) The "Gulf of Lion-Southern Alps" transect comprises the Southeastern French Alps, the Côte d'Azur, Languedocian Lagunas, a small continental depression in French Languedoc and Roussillon, Corsica Island and the Balearic islands;

(3) The "Maghreb" transect comprises 3 working areas: the Middle Atlas and the Moulouya River basin in Morocco, the Oued Cheliff river basin in Algeria, the Medjerda and Oued Zeroud-Merguellil river basins in Tunisia.

In each window, we develop multi-proxy palaeoenvironmental analyses (geomorphology, sedimentology, geochemistry, micromorphology, palynology, non-pollen palynomorphs, fire signature, phytoliths, etc.) around archaeological sites and geoarchaeological research into excavated sites, where archaeobotanical and archaeozoological research were also conducted. To present our investigations, we briefly summarize results the obtained on the regional scale in 4 RCC periods from the Early Holocene and the Neolithization process to the Late Holocene.

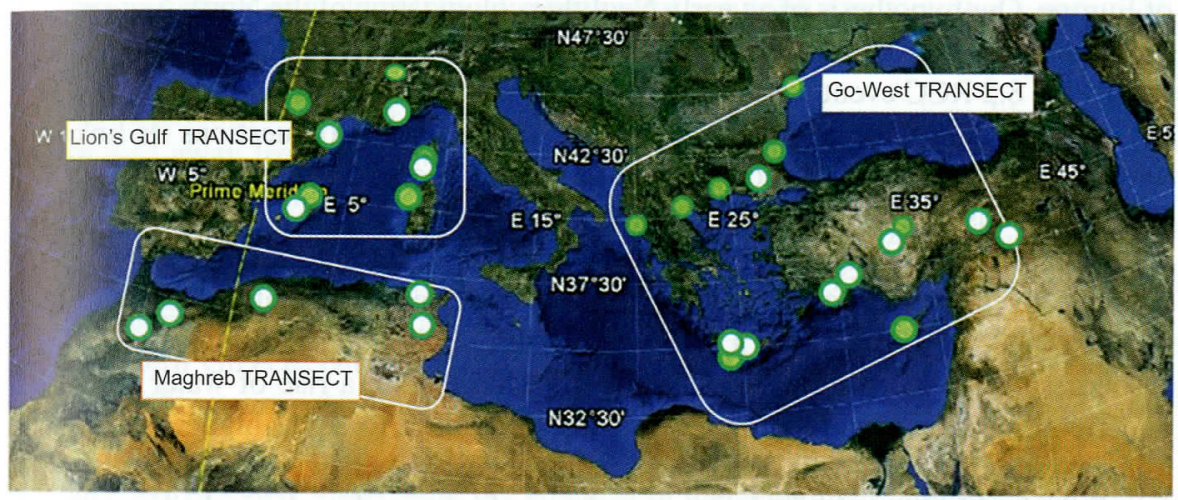

Continental data ArcheoMed (2012-2015)

Continental data ArcheoMed (2016-2020)

Figure 1

Areas investigated by the ArcheoMed-Paleomex project.

\section{2. ka BP event and the Neolithization Eastern Mediterranean}

The first question concerns the Early Holocene RCC's records in the Mediterranean zone, which are under-represented in continental archives (9.2 and $8.2 \mathrm{ka}$ events, c. 7.2 and $6.2 \mathrm{ka} \mathrm{BC}$ ) and their impact on prehistoric societies. 
We study river and lake systems, from the eastern to the central Mediterranean areas (Central Anatolia, Cyprus, NE and NW Greece) which represent continental archives where Early Holocene RCC events and their local impact on prehistoric societies can be or have been recorded.

The research demonstrates the reality of hydrogeomorphological responses to early Holocene RCCs in valleys and alluvial fans and lake-marsh systems (Berger et al. 2016). It highlights the importance of Holocene sedimentation and postdepositional disturbances on reading the Mesolithic-Early Neolithic transition and attests to the first true levels of Neolithic occupation in SE Europe. Terrestrial records still reflect heterogeneities in palaeoclimatic restitution across the northeastern Mediterranean during RCC events. They suggest a probable tripartite timing for the $8.2 \mathrm{ka}$ BP event revealed by a few Mediterranean marine records. These issues are crucial if we are to reach a clearer assessment of climate impact on coastal and continental environments, in major societal disruptions such as the Neolithization of the Mediterranean.

The probable tripartite timing of the $8.2 \mathrm{ka}$ events complicates our view of the link between climate change and the Neolithic development and colonization of Europe. Our hypothesis of an early Neolithic colonization of the North Aegean (around $8.4 \mathrm{ka}$ cal. BP), prior to the assertion of the second and more marked part of the 8.2 RCC event well registered in the western study area demonstrates the complexity and the reality of the climate change but also questions its link with the Neolithization promoted by certain researchers (e.g. Wenninger et al. 2014). We must keep in mind that the geographical setting of the Mediterranean results in physically very contrasting environments in which it is often sufficient to move over very short distances to find different environmental conditions (Lespez et al. 2016b). In fact, a dry period could imply a move closer to water resources or, on the contrary, as observed in Dikili Tash, a rise of water table and flood hazards might imply leaving the floodplain to settle higher on the alluvial fans or lower slopes in the surrounding areas. Only new research, closely interlinked with the multidisciplinary analyses of intra-archaeological sites will optimize our perception of forms of socioenvironmental resilience.

\section{5-5 ka BP Rapid Climatic Changes and the "lost millennium" in SE Balkan archaeology}

The second results discuss the interaction of nature and society in the Middle Holocene. At the end of the Late Neolithic, the period between 6.5 and $5 \mathrm{ka}$ cal BP (c. 4.5-3 ka BC) is one of the least studied episodes of RCC. This period is characterized by a dramatic decline in settlement and a cultural break lasting 
over 5 centuries in the South Balkans (Tsirtsoni, 2016). High-resolution paleoenvironmental proxy data obtained in northern Greece enables an examination of the societal responses to rapid climatic change (Lespez et al. 2016). The development of a lasting fluvio-lacustrine environment followed by enhanced fluvial activity is evident from $6 \mathrm{ka} \mathrm{cal} \mathrm{BP} \mathrm{(c.} 4 \mathrm{ka} \mathrm{BC}$ ) in the Lower Angitis and Strymon valley. Palaeoecological data show a succession of three dry events at 5800-5700, 5450 and 5000-4900 cal yr BP.

By comparison with the available regional data, it appears that these events correspond to the incursion of cold air masses to the eastern Mediterranean, confirming the climatic instability of the middle Holocene climate transition. Two periods with farming and pastoral activities during the Late to Final Neolithic (6.3-5.6 ka cal BP, c. 4.3-3.6 ka BC) and the Early Bronze Age (5.1-4.7 cal BP, c. 3.1-2.7 ka BC) evidently correspond to an increase in settlements on the regional scale. The intervening period is marked by environmental changes, but the continuous occurrence of anthropogenic taxa and fire signatures suggests the persistence of human activities and in particular, pastoralism, despite the lack of archaeological sites dated to this period and the weakness of archaeological evidence of continuity, raising the question of changes in settlement patterns.

The populations moved to cope with environmental change, but although they moved away from areas most affected by the rising water table, they probably settled in the foothills. The permanence, even slightly diminished, of anthropogenic indicators confirms the continuity of settlement in the Lower Angitis and Strymon Valley. As in other Eastern Mediterranean areas (e.g. Ghilardi et al. 2015), the abrupt succession of wet and dry periods could have affected the population of Northern Greece, but it is likely that the dry and cool conditions of the shorttime climate events alone were insufficient to trigger the observed societal changes. Archaeological surveys must be developed at the micro-regional scale in order to better understand the changes in the settlement patterns. This study highlights the high capacity for adaptation of Neolithic and Bronze age societies during climatic stress periods.

\section{2 ka BP climatic event and settlement pattern changes in western Mediterranean}

The third study focuses on the impact of environmental changes (so-called 4.2 ka BP event, c. $2.2 \mathrm{ka} \mathrm{BC)} \mathrm{on} \mathrm{ancient} \mathrm{societies,} \mathrm{from} \mathrm{the} \mathrm{recent} \mathrm{Neolithic} \mathrm{to}$ the Early Bronze Age in western Mediterranean areas (Carozza et al. 2015). A short period of drought in the Mediterranean may correspond to the establishment of the Mediterranean climate under orbital forcing (Magny et al. 2013). 
A series of studies have established that in the south of France, for instance in the Rhône valley, an important change occurred in the human settlement system around 2.3-2.2 ka BC. In lowland areas, after maximal concentration, the number of settlements decreased significantly along the river systems during a period of very high hydrosedimentary discharges, dryness, and fire activity (fig. 2). It is interesting to note that the exploitation of copper ore resources, which had begun in Cabrières (SW France) around 3.2 ka BC ceased around 2.3-2.2 ka BC.

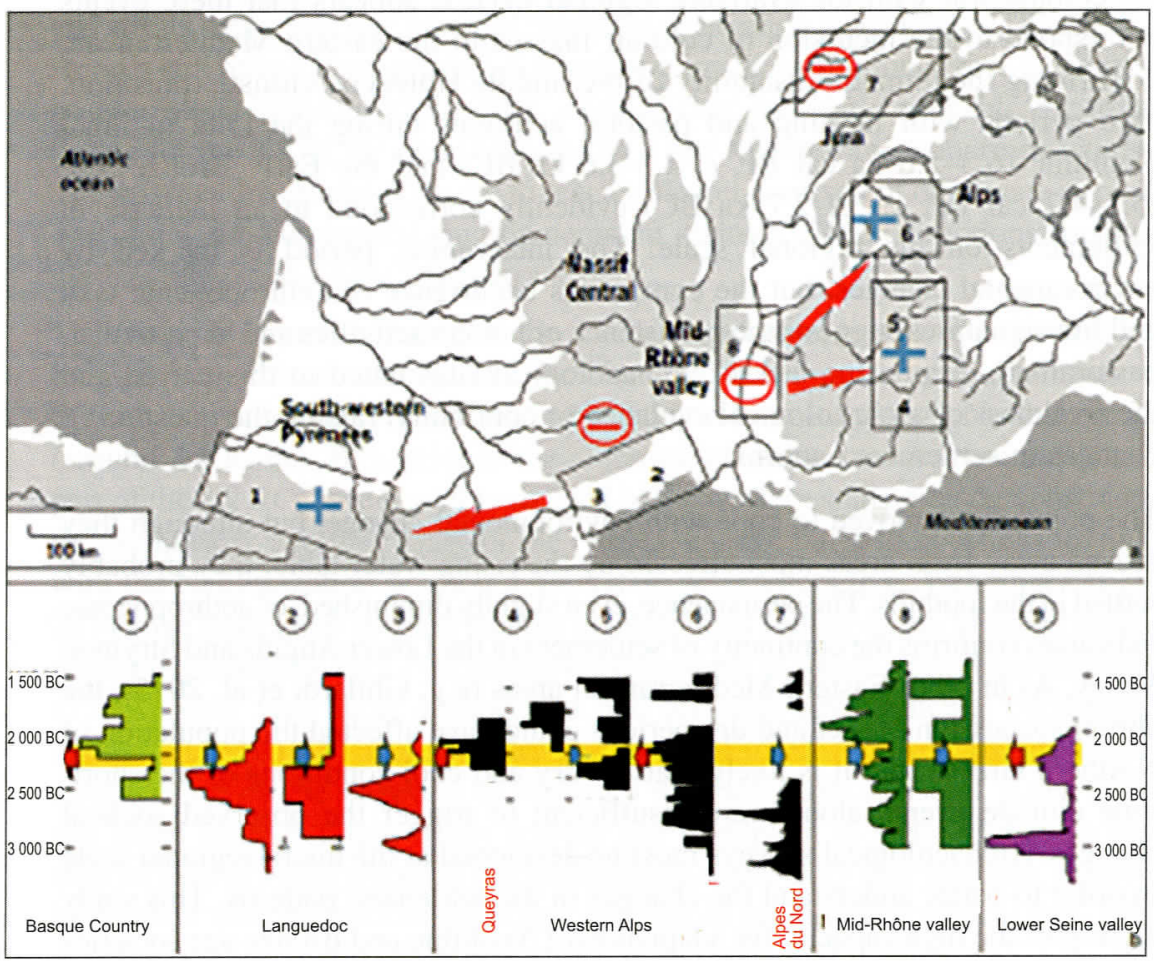

Figure 2

Map of the micro-regions documenting the Late Neolithic III to Early Bronze Age transition around $4.2 \mathrm{ka} \mathrm{cal} \mathrm{BP} \mathrm{(c.} 2.2 \mathrm{ka} \mathrm{BC}$ ).

I Western Pyrenees; 2 Languedoc plateau (Boussargues-Les Vautes); 3 Languedoc (Fontbouisse Culture); 4 southern Alps (Queyras, Saint-Véran); 5 central-western Alps (CPDF); 6 northern Alps (multi-source CPDF); 7 Jura/Swiss Plateau/Bavaria; 8 mid-Rhône valley; 9 Normandy (Alizay site, (PDF). Red minus signs - depopulated areas; blue plus signs - densely populated area; red arrows

- direction of possible mobility of people around the $4.2 \mathrm{ka}$ cal BP event. b Comparison of temporal dynamics of the same micro-regions illustrating spatial re-organisation throughout France. Blue arrows - sharp decline; red arrows - growth.

From Carozza et al. 2015.

At the same time, environmental changes allowed for an exploitation of alpine copper, as seen in Saint-Véran (SE France). Indeed, from 2.15-1.65 ka BC, the glacial retreat permitted the exploitation of copper ore resources at very high altitudes of above $2,400 \mathrm{~m}$ (Les Rousses, SE France). The archaeological findings 
have revealed a growth in human pressure in mountain areas, specifically in the Pyrenees (SW France). The exploitation of intermediate areas (from foothills to moderately mountainous regions) in the Basque Country took the form of temporary habitations (pastoralism). The period between 2.3 and $2.1 \mathrm{ka} \mathrm{BC}$ corresponds to a global environmental threshold phase in the south-north atmospheric circulation at the beginning of the Late Holocene, caused by an orbital forcing. In the same period, the effects of millennial-scale Rapid Climate Change (RCC) lasting three to four centuries (around the $4.2 \mathrm{ka} \mathrm{BP}$ event, c. $2.2 \mathrm{ka} \mathrm{BC}$ ) are recorded in the lake, fluvial and soil systems of Western Europe. It still seems to present a temporal tripartite structure with two wet periods in Southern France (Magny et al. 2013, Carozza et al. 2015). The socio-economic modifications show a decrease in lowland area occupation and an increase of settlement in mountainous areas and may have resulted in a spatial reorganization at a regional level, but not in a global societal collapse.

\section{2 ka BP climatic event and sustainability of agro-pastoral activities in Eastern Mediterranean}

The last case study concerns the transition from the Iron Age to the Middle Ages in the eastern Mediterranean area. In Anatolia, a complex rural system has been identified in many pollen records (Bottema and Woldring, 1984): the "Beyşehir Occupation Phase" (BOP). It is characterized by complementary productions (fruits, cereals, trees, vineyards, olives, animals etc.) and its chronology varies from place to place (Kuzucuoğlu, 2015; fig. 3). Depending on the recording site, it appears during the Late Bronze Age (LBA, the Hittite Empire), during the chiefdom and rural transition between LBA and Iron Age kingdoms (1.15-1 ka BC), and the beginning of the Iron Age (1-0.7 ka BC). It lasted until the Early Byzantium, ending at places between AD 450 and 750 (1.5-1.2 ka BP). While the end of the BOP is well correlated in central Anatolia with the Arab raids, its end in other areas seems to be more or less related to a contraction in rural settlement with no clear cause, mainly because it varies so significantly from region to region. The exceptional duration ( $>1,000$ years) of the BOP landscape in Anatolia, occurred in spite of many, well known, political turmoil and wars, as well as several, well known, climatic changes that succeeded in the Eastern Mediterranean from ca $1.3 \mathrm{ka} \mathrm{BC}$ to $0.7 \mathrm{ka}$ AD. The example of the "3.2 ka cal. BP event", well identified in central Anatolia (Kuzucuoğlu, 2015), is a good illustration of the necessary caution and nuancing required when arguing a decisive role for climate in the fate of major political events such as the silent vanishing of the Hittite Empire c. $1.17 \mathrm{ka}$ BC (without destruction). Central Anatolia is a region sensitive to rain-depletion-climatic 
"crises". In spite of the limits in ${ }^{14} \mathrm{C}$ dating inducing a c. 50-year leeway in the start and end dates of "rapid changes", climatic fluctuations as well as abrupt changes can be evidenced in several areas forming the large central Anatolian region, even when wet/dry alternations have been rapid.

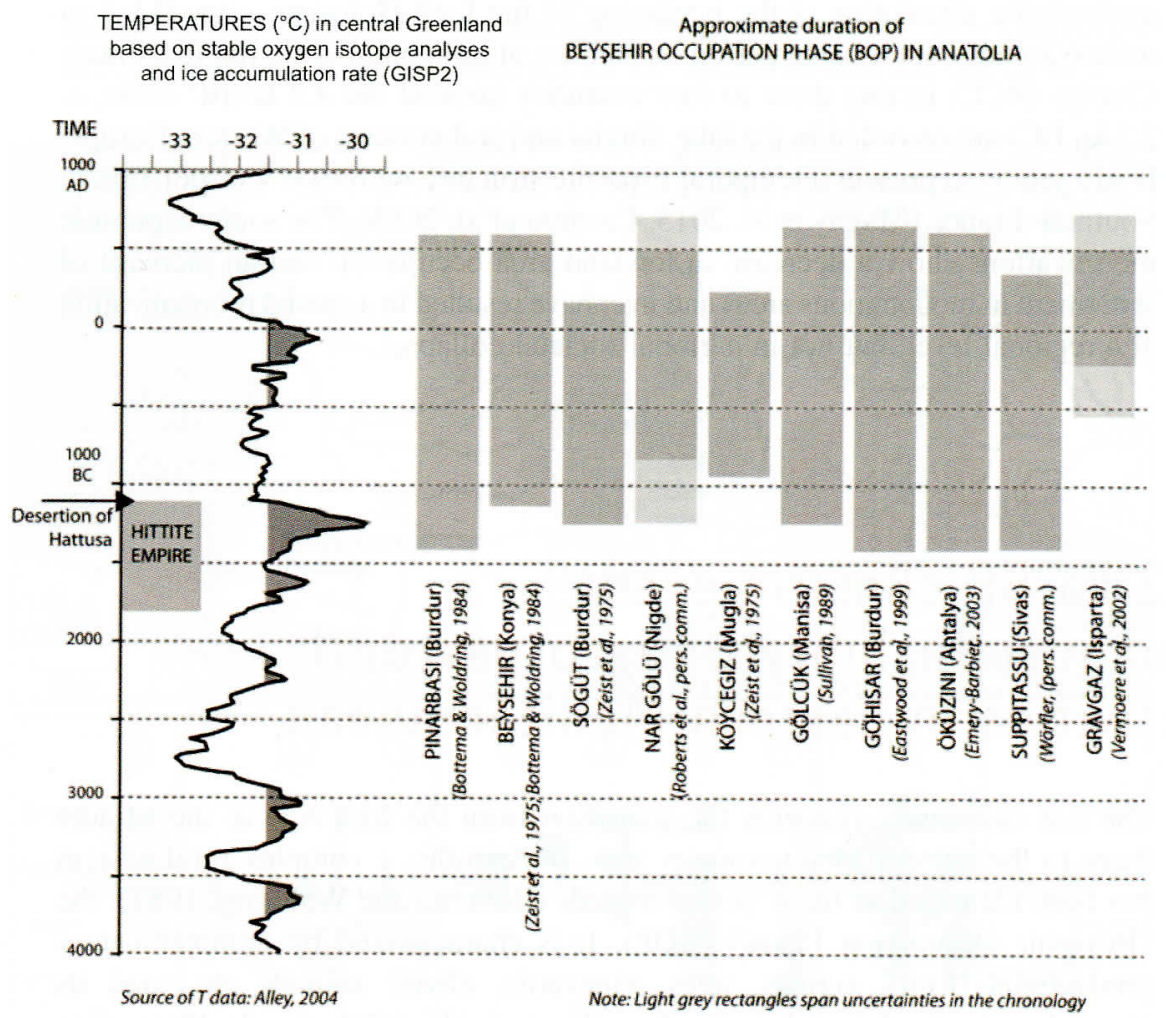

Figure 3

Climatic changes from the Hittite Empire to the medieval period and BOP timing in Anatolia. From Kuzucuoglu, 2015.

Here, the $2^{\text {nd }}$ half of the $2^{\text {nd }}$ mill. BC $(1.55-1 \mathrm{ka} \mathrm{BC}, 3.5-3 \mathrm{ka} \mathrm{cal} . \mathrm{BP})$ and the start of the 1st mill. BC (1-0.85 ka BC, 3-2.8 ka cal. BP) were characterized by several dry periods and drought spikes recorded by indicators in marsh, lake, river and slope sediments. Here several facts contradict the deterministic view of the climate role in history which assumes that climate causes both an irreversible decline of agriculture during increasing periods of dryness, and political destabilization resulting from migrations and wars motivated by resource depletion.

In fact, at the end of the $2^{\text {nd }}$ mill. $\mathrm{BC}$, neither the droughts nor the vanishing of the Hittite Empire, impacted the BOP at sites where it had started before $1.2 \mathrm{ka}$ BC. During the so-called " 3.2 ka cal. BP global event", the BOP proved its 
sustainability in spite of political changes and continuing dry conditions. The climate degradation which occurred in parallel with cultural disorders in the Eastern Mediterranean (Kuzucuoğlu 2012), acted in Anatolia as an external element leading, in the context of the disruption of the EM "world trade organization", to the end of a very centralized system and the development of an innovative cultural system. This example shows also that the degree of cultural sensibility to climate change is not obviously related to the intensity or nature of that change, but to the internal factors of vulnerability with regard to change: rigidity of social structures, centralization of decision, transmission networks, unbalanced distribution of resources and means for productions (e.g. equipment, land, technical innovation).

\section{Conclusion}

These 4 examples underline the uncertainties of chronology of so-called RRC at the local/regional scale without specific investigations and highlight the capability of societies to be resilient and/or to adapt to environmental transformations caused by climatic changes. Rather than collecting radiocarbon dates in order to propose the modelling of Nature/Society interactions, we need to have more case studies on a regional and Mediterranean scale if we are to reasonably discuss the role of climatic changes in cultural transformation. Where archaeological and local palaeoenvironmental data are still unexploited, our understanding of land use and historical dynamics is hindered, with many surprises still in store.

\section{References}

Berger J.F., Lespez L., Kuzucuoglu C., Glais A., Hourrani F., Guilaine J., 2016 Early to MidHolocene Neolithic/RCC interactions in center-eastern Mediterranean basin (Turkey, Cyprus, Greece). Climate of the Past (in press).

\section{BotTema S., Woldring H. 1984}

Late Quaternary vegetation and climate of Southwestern Turkey. Part II. Palaeohistoria 26: 123-149.
BUTZER, K.W., 2012

Collapse, environment, and society. Proceedings of the National Academy of Sciences 109, 3632-3639.

\section{Carozza, J.-M, Micu C., Mihail F.,} Carozza L. 2012

Landscape change and archaeological settlements in the lower Danube valley and delta from Early Neolithic to Chalcolithic time. Quaternary International, 261, 21-31. 
Carozza J.M., Llubes M., Danu M., Faure, M, Carozza L., David M., Manen C., 2016 Geomorphological evolution of the Mediterranean enclosed depressions during Pleistocene and Holocene: Example from Canohès (Roussillon, SE France), Geomorphology 273, 78-92.

Carozza, L., Berger, J. F., Burens-Carozza, A., Marcigny, C., 2015 Society and environment in Southern France from the $3 \mathrm{rd}$ millennium $\mathrm{BC}$ to the beginning of the 2nd millennium BC: $2200 \mathrm{BC}$ a tipping point? 2200BC-A climatic breakdown as a cause for the collapse of the old world? In Tagungen des Landesmuseum für vorgeschichte, Halle, Band 12, p. 333-362.

\section{DeMenocal, P., 2001}

Cultural responses to climate change during the Late Holocene. Science 292, 667-673.

\section{DRAKE, B.L., 2012}

The influence of climatic change on the Late Bronze Age collapse and the Greek Dark Ages. Journal of Archaeological Science 39, 1862-1870.

Flohr, P., Fleitmann, D., Matthews, R., MattheWs, W., BlaCK, S., 2016

Evidence of resilience to past climate change in Southwest Asia: Early farming communities and the 9.2 and 8.2 ka events, Quaternary Science Reviews, 136, 23-39.

Ghilardi M., Psomiadis D., Cordier S., Delanghe-Sabatier D., Demory F., Hamidi F., Paraschou T., Dotsika E., Fouache E., 2012 The impact of rapid early- to mid-Holocene palaeoenvironmental changes on Neolithic settlement at Nea Nikomideia, Thessaloniki Plain, Greece. Quaternary International, 266, 47-61.

Ghilardi M., Cordier S., Carozza J.M., Psomiadis D., Guilaine J., Zomeni Z., Demory F., Delanghe-Sabatier D., Vella M.A., Bony G., Morhange C., 2015 The Holocene fluvial history of the Tremithos River (south central Cyprus) and its linkage to archaeological records. Environmental Archaeology, 20 (2), 184-201.

GHILARDI M., ISTRIA D., CuRras A., Vacchi M., Contreras D., Vella C., Dussoulllez P., Crest Y., Guiter F., Delanghe D., 2016 Reconstructing the landscape evolution and the human occupation of the Lower Sagone River
(Western Corsica, France) from the Bronze Age to the medieval period, Journal of Archaeological Science Reports (in press).

\section{Glais A., Lopez-SAEZ J.-A.}

LESPEZ L., DAVIDSON R., 2016

Climate and human-environment relationships on the edge of the Tenaghi-Philippon marsh (Northern Greece) during the Neolithization process. Quaternary International, 403, 237-250.

\section{KuzucuoĞLu C., 2012}

Le rôle du climat dans les changements culturels, $\mathrm{du} \mathrm{V}^{\mathrm{e}}$ au $1^{\mathrm{er}}$ millénaire avant notre ère, en Méditerranée orientale. In: J-F. Berger (Ed.), Des climats et des hommes, Paris: 239-256.

\section{KuzucuoĞLu C., 2015}

The rise and fall of the Hittite State in central Anatolia: how, when, where, did climate intervene? In: O. Henry, D. Beyer, A. Tibet (Eds), Archaeological Research in southern Cappadocia, IFEA-Varia Anatolica, Ege Yay., Istanbul: 17-41.

LeSPEZ L., Glais A., López-SÁEZ J.-A., Le Drezen Y., Tsirtsoni Z., Davidson R., Birée L., Malamidou D., 2016

Mid-Holocene rapid environmental changes and human adaptation in Northern Greece. Quaternary Research 85, 2, 227-244.

LESPEZ, L., TSIRTSONI, Z.,

Darceue, P., Malamidou, D.,

Koukouli-Chryssanthaki, H., Glais, A., 2016 Identifying the earliest Neolithic settlements in the South-Eastern Balkans: methodological considerations based on the recent geoarchaeological investigations at Dikili Tash (Greek Eastern Macedonia). In: Going West? The spread of farming between the Bosporus and the Lower Danube Region, EAA - Themes in Contemporary Archaeology, Edited by Tsirtsoni Z., Reingruber A., Nedelcheva P., Maney publishing, (in press).

Magny, M., Combourieu Nebout, N., DE Beaulieu, J.L., Bout-Roumazeilles, V., Colombaroli, D., Desprat, S., Francke, A., Joannin, S., Peyron, O., Revel, M., Sadori, L., Siani, G., Sicre M-A., S., Samartin, M.A., Simonnead, A., Tinner, W., Vannière, B., Wagner, B., Zanchetta, G., Anselmetti, F. Brugiapaglia, E., Chapron, E., Debret, M., Desmet, M., Didier, J., Essallami, L., Galop, D., Gilli, A., HaAs, J.N., Kallel, N., Millet, L., Stock, A., Turon, J.L., WirTh, S., 2013 North-south palaeohydrological contrasts in the 
central Mediterranean during the Holocene: tentative synthesis and working hypotheses. Climate of the Past 9, 2043-2071.

\section{TSIRTSONI, Z. (ED.), 2016}

The Human Face of Radiocarbon: Reassessing Chronology in Prehistoric Greece and Bulgaria, 5000-2000 cal BC, Travaux de la Maison de l'Orient et de la Méditerranée, Lyon, 304p.

\section{Vannière B., Magny M., Joannin S.,} Simonneau A., Wirth S. B., Hamann Y., Chapron E., Gilli A., Desmet M.,

\section{ANSELMETTI F. S., 2013}

Orbital changes, variation in solar activity and increased anthropogenic activities: controls on the Holocene flood frequency in the Lake Ledro area, Northern Italy, Clim. Past 9, 1193-1209.

Vannière B., Blarquez O., Rius D., Doyen E., Brücher T., Colombaroli D., Connor S., Feurdean A., Hickler T.,
Lemmen C., Leys B., Massa C., Olofsson J., 2016

7000-year human legacy of elevation-dependent European fire regimes. Quaternary Science Reviews 132, 206-212.

Weiss, H., Courty, M.A., Wetterstrom,W., Guichard, F., Senoir, L., Meadow, R., Curnow, A., 1993

The genesis and collapse of third millennium North Mesopotamian civilization, Science 261, 995-1004.

Weninger, B., Clare, L., Gerritsen, F., Horejs, B., Krauss, R., Linstädter, J., Özbal, R., Rohling, E.J., 2014

Neolithisation of the Aegean and Southeast Europe during the $6600-6000 \mathrm{cal} \mathrm{BC}$ period of rapid climate change. Documenta Praehistorica 41, 1-31. 
This book has been published by Allenvi (French National Alliance for Environmental Research) to coincide with the $22^{\text {nd }}$ Conference of Parties to the United Nations Framework Convention on Climate Change (COP22) in Marrakesh. It is the outcome of work by academic researchers on both sides of the Mediterranean and provides a remarkable scientific review of the mechanisms of climate change and its impacts on the environment, the economy, health and Mediterrainean societies. It will also be valuable in developing responses that draw on "scientific evidence" to address the issues of adaptation, resource conservation, solutions and risk prevention. Reflecting the full complexity of the Mediterranean environment, the book is a major scientific contribution to the climate issue, where various scientific considerations converge to break down the boundaries between disciplines.

The preface, introductory pages, chapter summaries and conclusion are published in two languages: French and English.

La préface, les pages introductives et de conclusion ainsi que les résumés de chapitres sont publiés en version bilingue anglais / français.
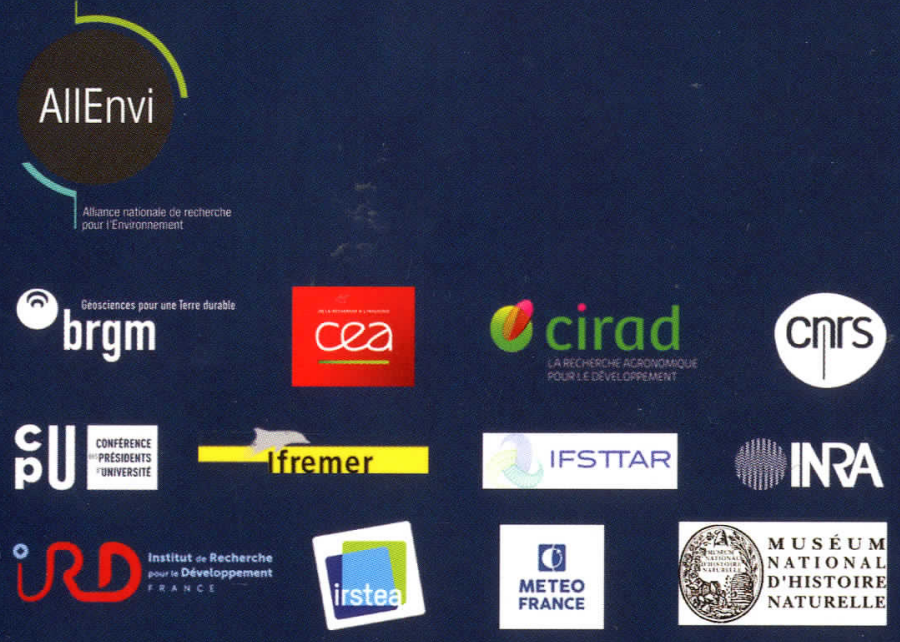

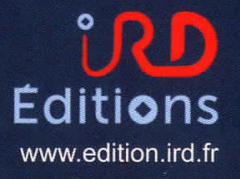

ISBN 978-2-7099-2219-7

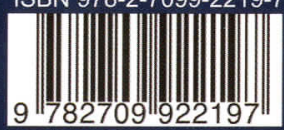

